\title{
Geochemical data for produced waters from conventional and unconventional oil and gas wells: Results from Colorado, USA
}

\author{
Yousif Kharaka ${ }^{1, *}$, Kathleen Gans ${ }^{1}$, James Thordsen ${ }^{1}$, Madalyn Blondes ${ }^{2}$, and Mark \\ Engle ${ }^{2,3}$ \\ ${ }^{1}$ U. S. Geological Survey, Menlo Park, California; \\ ${ }^{2}$ Reston, Virginia, USA \\ ${ }^{3}$ Dept. of Geological Sciences, University of Texas at El Paso, El Paso, Texas
}

\begin{abstract}
Geochemical data for more than 120,000 oil and natural gas wells from the major sedimentary basins in the USA are listed in the USGS National Produced Waters Geochemical Database [1]. In this summary, we report and discuss the geochemical data on produced waters obtained from published literature and the Colorado Oil and Gas Conservation Commission (COGCC) from close to 4,000 new oil and gas wells in Colorado. We emphasize geochemical data of produced waters from shale and tight reservoirs that have increased dramatically in Colorado since 2011, due to deep horizontal drilling, downhole telemetry and massive multi-stage hydraulic fracturing. These operations require large volumes of fresh water, but contamination of groundwater is the major environmental concern. Also, induced seismicity caused by water injection has been reported from several areas in Colorado, including Trinidad, Raton basin, and Greely, Denver basin. Produced water salinities in Colorado obtained from unconventional oil and gas wells are relatively low, generally less than $30,000 \mathrm{mg} / \mathrm{L}$ TDS. Produced water salinities from conventional oil and gas wells overlap those from unconventional wells, but many wells have higher salinities (up to $90,000 \mathrm{mg} / \mathrm{L}$ TDS) and different chemical compositions.
\end{abstract}

\section{Introduction}

Approximately 5 million oil and natural gas wells have been drilled in the USA since 1859, when the first oil well, the Drake Well, was completed near Titusville, Pennsylvania [2]. Detailed geochemical data are available for many of these wells, including locations, perforated depths and types of reservoir rocks, together with the chemical and isotopic compositions of produced waters collected during production of oil and natural gas, or obtained from drill-stem tests [3]. Such geochemical data for more than 120,000 oil and gas wells from the major sedimentary basins in the USA, were obtained from published literature and received from oil companies and state divisions of oil and gas. The data are listed in the updated USGS National Produced Waters Geochemical Database [1]. These

*Corresponding author: ykharaka@usgs.gov 
data carry large uncertainties and require additional culling and analysis, but the databases are an important resource for those interested in determining the geochemical nature of deep formation waters, contamination sources, and impacts of hydraulic fracturing [1].

Approximately $90 \%$ of wells in the USGS Database were drilled by conventional technologies. More recently geochemical data for produced waters have also been obtained from production of gas and oil from unconventional energy sources that include shale and very low permeability $(<0.1 \mathrm{mD})$ sandstones as well as coal bed methane (CBM). Production of oil and gas from shale and tight reservoirs has increased dramatically in the USA due to recent developments in deep horizontal drilling, downhole telemetry and massive multi-stage hydraulic fracturing [4-6]. The current version (v2.3) of the USGS Database [1] contains geochemical data for $\sim 15,000$ wells for shale gas, tight oil and gas, and CBM. The rapidly expanding oil and gas production from shale started in 1991 with a well in the Barnett Shale of Texas, and spread rapidly to other basins, including the Appalachian Basin, producing gas from the Marcellus Shale in Pennsylvania starting in 2005, and to Williston Basin producing oil from the Bakken Formation in 2007 [6]. For the USA in 2017 , about $50 \%$ of oil and $67 \%$ of natural gas productions were obtained from shale and tight reservoirs. Fracturing horizontal wells is carried out by injecting large volumes $\left(10,000-40,000 \mathrm{~m}^{3} /\right.$ well) of generally fresh water with added proppant (sand or ceramic) and organic and inorganic chemicals at pressures high enough to fracture the reservoirs. Fractures, which are kept open by the proppant particles, direct the flow of petroleum and brine into the well, that direct it to ground level [7-9].

In this summary, we report and discuss the new geochemical data on produced waters obtained from published literature and the COGCC from $\sim 4,000$ oil and gas wells drilled in sedimentary basins in Colorado. We emphasize geochemical data of produced waters from CBM, shale and tight reservoirs, which were not included in version 2.3 [1]. These data are compared with those collected from conventional wells in the state obtained for this study as well as approximately 2,000 wells reported in [10]. We also discuss the water requirements for the drilling and hydraulic fracturing of tight reservoirs as well as the potential for groundwater contamination and induced seismicity associated with this new important source of energy.

\section{Oil and Gas Development in Colorado}

Oil and gas development in Colorado started in 1862, and the state has 10 of the nation's 100 largest natural gas fields and three of its 100 largest oil fields [11]. This abundance is due to the geology of the state, which includes the large Niobrara shale formation in northeast Colorado, numerous sedimentary basins (Fig. 1), and significant deposits of methane-bearing coal [11]. The Niobrara shale is a major reservoir in the Wattenburg, the fourth largest US oil field in which oil and gas developments have accelerated using hydraulic fracturing and horizontal drilling starting in 2011 [11, 12]. The San Juan and Raton basins in southern Colorado contain large quantities of CBM, while the Piceance basin in western Colorado has large amounts of conventional gas (Fig. 1). There are currently close to 50,000 active oil and gas wells in Colorado, about half are located in Weld County, in the Denver-Julesberg Basin, which produces $90 \%$ of Colorado's oil and $1 / 3$ of their natural gas [11].

Production of CBM grew rapidly in the 1990s and typically accounted for one-third of Colorado's total gas production. Recent lower natural gas prices have rendered some CBM wells uneconomic, and production of CBM fell to almost one-fifth of Colorado's total in 2016 [11]. Colorado has $>1 / 3$ of U.S. proved CBM reserves, and nearly all CBM is produced in the San Juan and Raton Basins (Fig. 1) located in southern Colorado [13]. 
For Colorado in 2017, the total oil, water, CBM and total gas (including CBM) productions were: 120 million bbl, 308 million bbl, 290 billion $\mathrm{ft}^{3}$ and 1.71 trillion $\mathrm{ft}^{3}$, respectively. The produced water/oil ratio in Colorado is low, only 2.34 for 2017 [11], compared to 11 for the USA and 16 for California $[2,14]$. The water/oil ratio is much lower for oil and gas obtained from unconventional wells. Thus, it is only 0.47 for Weld County with dominantly unconventional production, but higher (18.2) for Garfield County (Piceance Basin) and higher in 2007 (14.2) before the onset of unconventional petroleum production [14].

Exploration for and production of oil and gas cause major local surface land disturbance, air and noise pollution, and habitat fragmentation and other ecological impacts [15-17]. Potential contamination of surface water and groundwater are the major environmental concerns [15-17]. However, induced seismicity from produced water

\section{Colorado TDS (mg/L)}

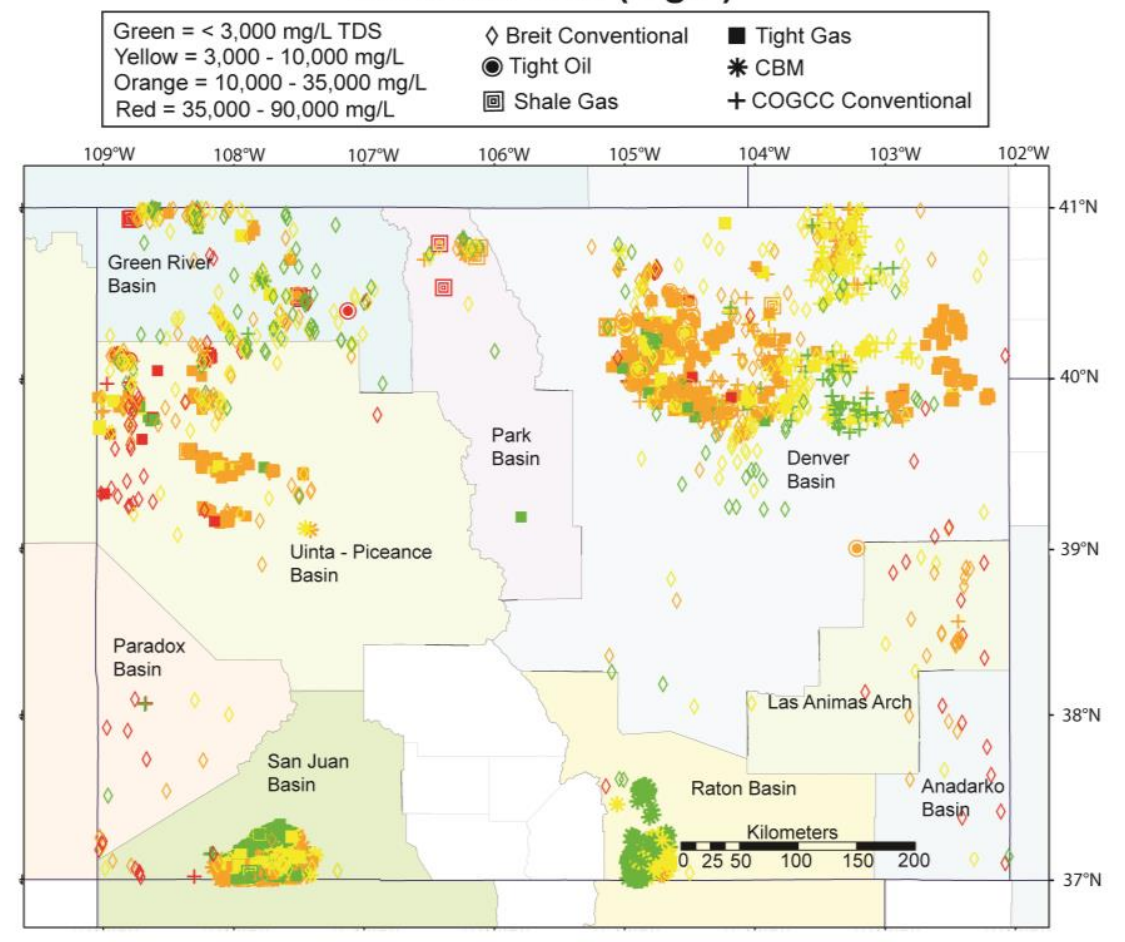

Fig. 1. Salinity (TDS in $\mathrm{mg} / \mathrm{L}$ ) of produced waters in the major sedimentary basins in Colorado.

injection and other production-related activities in Colorado is reported to have increased dramatically recently in several areas in Colorado, including Trinidad (Raton basin), Greely (Denver basins), and Bedrock (Paradox Valley) [11, 18].

\section{Salinity and Composition of Colorado Produced Waters}

Geochemical data on produced waters from $\sim 6,000$ oil and gas wells in Colorado are listed in a table that is too large for this summary, but will be published in v2.4 of the updated USGS Produced Waters Database [1]. Figure 2 shows the TDS vs depth of midpoint of perforation of the reservoir rocks for this data set. The reported salinities and chemical compositions of water for these and similar samples can vary widely with time of sampling, especially for the 'flowback' samples that are, for several months following the start of 
production, a variable mixture of pore formation water and the hydraulic fracturing fluids $[7,15]$. Chemical analyses of formation water from some gas wells, especially those from reservoirs at temperatures $>100{ }^{\circ} \mathrm{C}$, may not represent the true chemical composition of formation waters from the production zones because of dilution by mixing with condensed water vapor coproduced with natural gas. This problem is particularly severe in wells that produce small volumes of water relative to the amount of natural gas, $<0.16 \mathrm{~m}^{3}$ of water per $\sim 3 \times 10^{4} \mathrm{~m}^{3}$ of gas $\left(<10\right.$ bbl per million $\left.\mathrm{ft}^{3}\right)$ [3].

Produced water salinities in Colorado obtained from unconventional oil and gas wells are relatively low, generally less than $30,000 \mathrm{mg} / \mathrm{L}$ TDS, and less than $20,000 \mathrm{mg} / \mathrm{L}$ TDS for CBM samples (Fig. 2). Produced water salinities from conventional wells (Fig. 2) overlap those from unconventional wells, but many wells have higher salinities, up to $90,000 \mathrm{mg} / \mathrm{L}$ TDS. Detailed examination of the chemical compositions of produced waters shows major differences--samples from $\mathrm{CBM}$ wells are $\mathrm{Na}-\mathrm{HCO}_{3}$ or $\mathrm{Na}-\mathrm{Cl}$ type waters, but

\section{Depth vs. TDS}

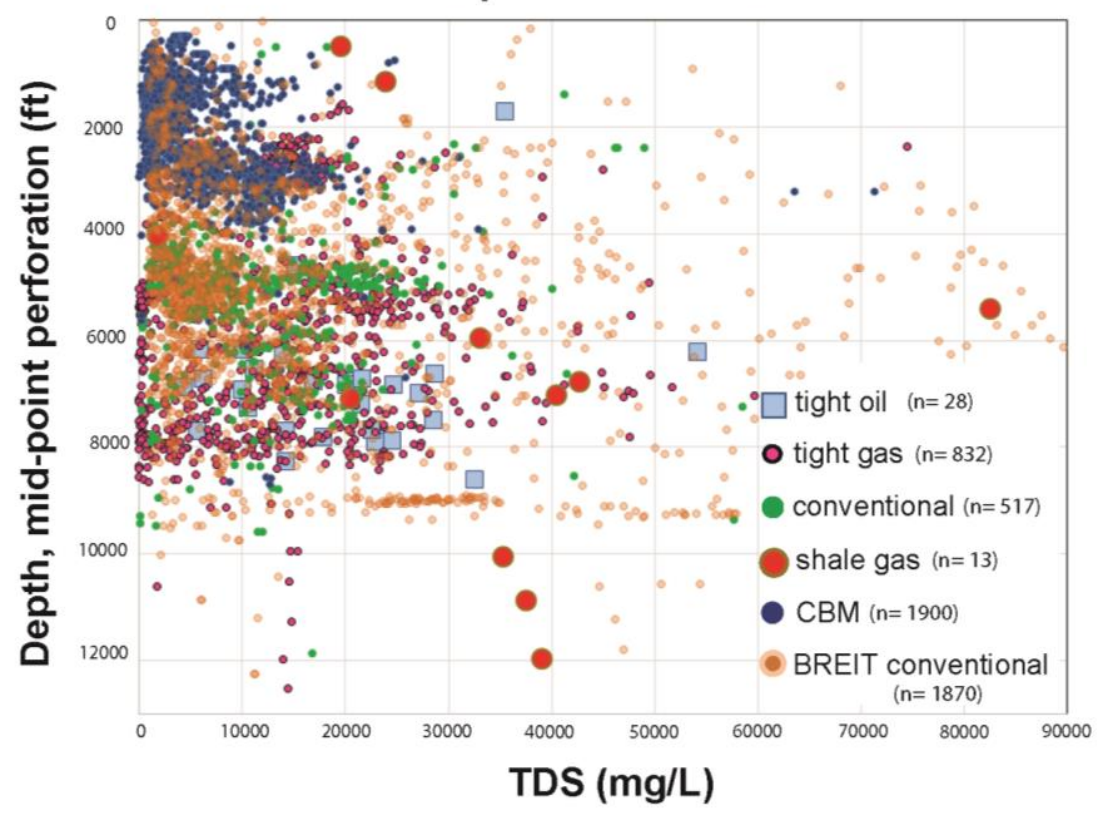

Fig. 2. Produced water salinity-depth distribution in Colorado conventional and unconventional fields. Note the low salinity ( $<20,000 \mathrm{mg} / \mathrm{L}$ TDS) of produced waters from CBM wells.

samples from the other unconventional wells are mainly $\mathrm{Na}-\mathrm{Cl}$ type waters. Conventional oil and gas wells also produce $\mathrm{Na}-\mathrm{Cl}$ type waters, but many have higher $\mathrm{Ca}$ and lower $\mathrm{HCO}_{3}$ concentrations that make them Na-Ca-Cl type waters (Fig. 3). 


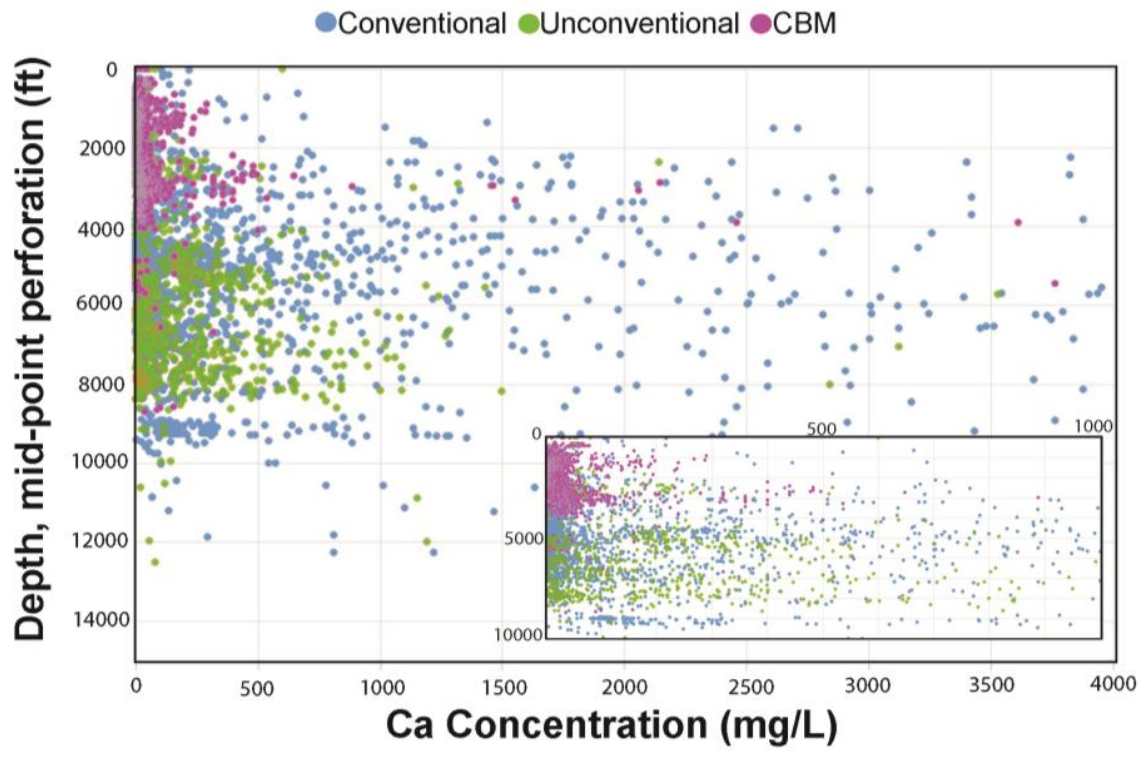

Fig. 3. Ca concentration vs depth of reservoirs for produced waters in CBM, conventional and unconventional oil and gas wells in Colorado. Note that mainly samples from conventional wells have high $\mathrm{Ca}$ values, and most of the samples from $\mathrm{CBM}$ and unconventional wells plot in the inset figure.

\section{Conclusions}

The approximately 6000 data points obtained from oil and natural gas wells in Colorado cover a major gap in version 2.4 of the USGS Produced Waters Geochemical Database [1]. Produced water salinities from $\sim 4000$ unconventional oil and gas wells are relatively low, generally $<30,000 \mathrm{mg} / \mathrm{L}$ TDS (Fig. 2). Produced water salinities from conventional wells overlap those from unconventional wells, but many wells have higher salinities, up to 90,000 mg/L TDS, and different chemical compositions (Fig. 3). These and similar data carry large uncertainties and require additional culling and analyses if used to obtain useful geochemical data on the scale of petroleum fields and basins. But such databases could provide an important resource for those interested in determining the general geochemical nature of deep formation waters, contamination sources, water reuse and other produced water issues on a basin scale.

\section{References}

1. M.S. Blondes, K.D. Gans, M.A. Engle, Y.K. Kharaka, M.E. Reidy, V. Saraswathula, J.J. Thordsen, E.L. Rowan, E.A. Morrissey, U.S. Geological Survey National Produced $\begin{array}{llllll}\text { Waters } & \text { Geochemical } & \text { Database } & \text { v2.3 (2018), } & \text { v2.4 } & \text { (2019) }\end{array}$ https://energy.usgs.gov/EnvironmentalAspects/EnvironmentalAspectsofEnergyProduct ionandUse/ProducedWaters.aspx\#3822349-data

2. IHS. Enerdeq - Energy Information Access and Integration Platform, (2018)

3. Y.K. Kharaka, J.S. Hanor, Surface and Groundwater, Weathering and Soils. 471-515 (Elsevier Science, Amsterdam, 2014)

4. E.L. Rowan, M.A. Engle, T.F. Kramer, K.T. Schroeder, R.W. Hamack, M.W. Daughten, AAPG Bulletin, 99, 181-206 (2015) 
5. A.G. Ilgen, J.E. Heath, I.Y. Akkutlu, L.T. Bryndzia, D.R. Cole, Y.K. Kharaka, T.J. Kneafsey, K.L. Milliken, L.J. Pyrak-Nolte, R. Suarez-Rivera, Earth-Science Rev. 166, 132-152, (2017)

6. U.S. Energy Information Administration (EIA), Annual Energy Outlook 2018 with Projections to 2050. Report \#AEO 2018. www.eia.gov/aeo (2018)

7. J.P. Nicot, B.R. Scanlon, R.C. Reedy, R. Costley, Env. Sci. \& Tech. 48, n. 4, 24642471, http://doi.org/10.1021/es404050r (2014)

8. T.J. Gallegos, B.A. Varela, S.S. Haines, M.A. Engle, Water Resources Research, 51 n. 7 10.1002/2015WR017278 (2015)

9. N.R.Warner, T.H. Darrah, R.B. Jackson, R. Millot, W. Kloppmann, A. Vengosh, E.S.\&T. 48, 12552-12560 (2014)

10. G.N. Breit, C.C. Skinner, Produced Waters Database: U.S. Geological Survey Provisional Release (May 2002) http://energy.cr.usgs.gov/prov/prodwat/index.htm

11. Colorado Oil and Gas Conservation Commission (COGCC) (2018)

12. P.H. Nelson, and S.L. Santus, USGS Open-File Report 2011-1175, 2 pls. (2011)

13. C.A. Rice, V.F. Nuccio, U.S. Geological Survey Fact Sheet FS-156-00, http://pubs.usgs.gov/fs/fs-0156-00/ (2000)

14. J. Veil, U.S. Produced Water Volumes and Management Practices in 2012. Report prepared for Ground Water Protection Council. Veil Environmental, LLC, (2015)

15. Y.K. Kharaka, D.R. Gans, J.J. Thordsen, M.S. Blondes, M.A. Engle, Subsurface Science and Engineering of Shale, John Wiley \& Sons, Inc., in print (2018)

16. U.S. EPA, Assessment of the Potential Impacts of Hydraulic Fracturing for Oil and Gas on Drinking Water Resources. EPA/600/R-15/047 (2015)

17. Vengosh, W.A. Mitch, L.M. McKenzie, E.S.\&T. 51, 10271-10273 (2017)

18. W.L. Ellsworth, Science, 341, doi:10.1126/science.1225942. (2013) 